water and alcohol. It forms copious precipitates with many of the metallic salts. Sulphuric; and hydrochloric acids cause a slight previpitate from the aquenus decoction; chlorine, a more copions one; the vitric gives no precipitate, but changes the color to a red. Tannin exists very sparingly. Sulphate of iron gave a dark green precipitate, which subsided in a sbort time. On distillation, water came over, very slightly affected with the sensible qualities of the plant, and not alterable by sulphate of iron.

Some difference of opinion has existed among the advorates of the Eupatorium, which portion of the plant was to be used. Dr. Andersnn concluded, from his experiments, that the active properties resided in the greatest quantity in the leaves; in this opinion he is upheld by $\mathrm{Dr}$. Chapman and oibers, but nore extended observations have shown that every part of the plant may be advantageously used.

All the species of Eupatorium appear in be endowed with medicinal qualities in a greater or less degree, and some of them have attained no little celebrity as antidotes agaiust the bite of venomous reptiles.

E. cannabinum, a native of Europe, was at one time in high repute as a deobstruent; but the recent experinents of Deslungclsamps and others show that its therapeutic powers have been much overrated.

E. Aya pana, a native of Brazil, was also considered entitled to a conspicuous rank as a universal panacea, and alexipharmic. A careful examination and trial of its reputed power's has, however, fully proved that, like many other equally vaunted articles, it was, comparatively speaking, inert.

In the United States, also, there are several speries which require notice, more especially the E. teucrifolium, or wild hoarhound. Dr. Jones of Georgia says that this plant "seems an excellent substitute for the Peruvian bark ; indeed, among the planters on or near the seaboard, it supersedes the use of the bark in the cure of fevers." He also remarks, "it is tonic, diaphoretic, diuretic, and mildly cathartic, and does not oppress the stomact as Peruvian bark is apt to do." The dose is one ounce of the leaves infused in a quart of water, which may be taken daily in doses of from two to four ounces every bour or two.

It is probable that inost of our native species might be used as substitutes for the E. perfoliatum, more especially the E. purpurcum and E. niaculatum.-Jour. of the Phila. Col. of Pharmacy.

\title{
ON THE MEDICAL USES OF THE VIOLA OVATA.
}

BY STEPHEN W. WILLIAMS, M.D. OF DEERFIELD, MASS.

Viola ovata. Synonym. Viola prinulifolia, Pursh. Rattlesnake violet. Specific Description. It is thus described by Nuttall. Leaves ovate, subcordate, crenate, rather acute, often larerately tonthed at the base; equally and for the most part conspicuously pubescent on either side, petiole inarginated; scape shorter than the leaves; segments of the calyx subriliate; petals obovate, the two lateral ones bearded. On dry land. Flowers bright blue; fluwers in April and May. (North Ameri- 
can genera.) I have ventured to give it the English name of rattlesnake violet, from the fact that it is generally known lere by the name of the rattlesnake plantain, from its efficacy in curing the bite of that reprile.

Medical Usc. - The fact which I shall relate with regard to its eflicary in arresting the direful efferts of the bite of the deadly rattlesnake, may be inplicilly relied on. Dr. Wells, when living, was considered one of the most eminent, judicious, and observing physicians which Massachusetts has ever claimed. His medical prevepts and opinions are treasured up hy many of his surcessors with religious veneration.

Let it not be objected to the Viola ovata that we are not acquainted with the active principle of the plant which thus rapidly arrests the progress of one of the most terrible accidents to which humanity is liable. The prineipal substance which can be extracted from it is mucilage, and this is best done by infusion in water. It yields a greater proportion of it than any of the violets, and nearly as much as the same quantity of slippery elm (Ulmus fulva) ; hence it is much in use in dysentery, diarrhoea, strangury, and other affections of the urinary organs. Other inedicinal qualities may reside in the plant, but I have not discovered thern. I cannot persuade inyself that its specific qualities reside in the mucilage, for other substances yield mucilage in greater abundance, and are not considered alexiplanimic. We ought always to be governed by facts rather than speculative opinions. Who can explain the reason why variola vaccina protects the system against the ravages of sinallpox? and yet who can doubt the fact? If we can establish the prophylactic qualities of the ratllesnake violet upon as firn grounds, or if we can be instrumental in saving the life of a fellow being laboring under the effects of the bite of this venomous reptile, our olject will be accomplished.

Many years ago rattlesnakes abounded in the vicinity of this place. Siuce the land is clearerl, they are rarely to be seen. Our old people were in the habit of using this violet for their bites. They generally know it by the name I have designated. The venerable Henry Wells, M.D., late of Montague, successfully emplnyed it in these cases. To his statement respecting it I wish to draw the attention of physicians. He was called to a patient who was bitten by a ratlesnake, and who was laboring under all the symptoms of a diffusion of the venom. His body was enormously swollen, respiration laborious, and his skin livid. He immediately directed a strong infusion of the rattlesnake violet, and constantly bathed the wound and body with it. In a few hours the tumefaction subsided, the febrile symptoms abated, and the patient was considered nearly out of danger. He retired to rest, and left directions with the nurse to give the violet tea often during the night. The patient continued so much better that the nurse became negligent, and omitted the directions, and fell asleep. From this suspension of the remedy the patient relapsed, and the fribrile symptoms returned, and the body was swollen like a puff-ball. The doctor was called, and again directed the remedy as before mentioned: the sympinms yielded, and from a continuance of the remedy two or three days he completely recovered without the use of any other means. Dr. Wells related the above fact to my father, who was formerly a physician in this town, and at the same time 
showed him the plant, which my father perfectly recollected, when I collected it for preservation in my herbarium.

My grandfather, Dr. Thomas Williams, formerly of this town, was in the constant habit of using a plant for the bite of the rattlesnake, which he called the rattlesnake plantain, and he was uniformly successful in the use of it. His practice as a physician and surgeon was very extensive. I have no doubt that it was the violet now under consideration.

I have within a few days ceased visiting a little patient who says that a short time before I was called to him he was bitten by a small green snake upon the top of his foot. Not long afterwards he was attacked with pain in his leg, attended with considerable swelling and high fever. I did not see him until he had been laboring under these symptoms some time. When I first saw him I did not apprehend that the fever, tumefaction, \&c. proceeded from the bite of the strake, for I was not aware that its bite was venomous. I put him upon the antiphlogistic plan of treatment, and applied the vegeto-mineral water to the inflamed leg. The next day I visited him, and found his symptoms aggravated, and the swelling increasing. I threw aside the mineral water, and directed emollient fomentations with the rattlesnake violet, and a poultice made with bran stirred into the liquor of the infused leaves. The next morning I was highly pleased with the success of the applications. The tumefaction had subsided, and the fever abated. I left him under a confident expectation that he would soon recover. In the course of the afternoon, however, an officious, intermeddling old woman sent word to the parents that my applications were improper, and that nothing would cure him but a cold application of the leaves of houseleek (Sempervivum tectorum), which was accordingly applied. The consequence was a universal chill, succeeded by delirium, and an intense burning fever, from which he was not relieved under several days. He was immediately attacked with pain and inflammation in the groin of the other leg, attended with a good deal of swelling. I was immediately sent for, but could not go until the next morning. I directed the violet fomentations and poultices again. In about a fortnight suppuration occurred, and I let out about half a gill of pus upon the tibia, about half way between the knee ${ }^{\cdot}$ and instep. The other leg continued swelled three or four weeks longer, when, by the continued application of the violet poultice, it subsided.

I bave since used the infusion of this violet, and a fomentation with the leaves of it, in an obstinate case of chronic inflammation of the eyes, which had resisted the long-continued use of a great variety of remedies. The patient had used the slippery elm and various other mucilaginous preparations with no success ; in fact, with rather an aggravation of the complaint. Within a fortnight from the time she commenced with the violet infusion, no traces of inflammation about the eyes remained. So it appears it must be some other quality in the violet than its mucilaginous properties which must have effected the change. I am determined in future to use it extensively in the phlegmasiæ, both acute and chronic. American Journal of the Medical Sciences. 